\title{
IKLAN LAYANAN KESEHATAN MASYARAKAT (ILKM); KAJIAN SEMIOTIK
}

\author{
I Made Suwitra, Nyoman Suarjana \\ Program Studi Kesehatan Masyarakat, Universitas Dhyana Pura \\ Email: imade.suwitra@yahoo.com
}

\begin{abstract}
ABSTRAK
Iklan layanan kesehatan masyarakat (ILKM) cenderung bertujuan untuk memberikan informasi, mengingatkan, menambah nilai, memengaruhi, dan bahkan mengubah sikap masyarakat untuk hidup sehat. Namun tidak banyak iklan layanan kesehatan masyarakat bersifat persuasif sehingga tidak cukup berkontribusi maksimal dalam mengajak masyarakat untuk hidup sehat. Oleh karena itu di dalam penelitian ini, iklan layanan kesehatan masyarakat yang cukup sering ditayangkan di media televisi menarik untuk diteliti karena memiliki karakteristik berbeda. Tujuan dari penelitian ini yaitu untuk mengetahui bagaimana gaya bahasa, makna, dan ideologi iklan layanan kesehatan masyarakat (ILKM). Hasil penelitian ini menunjukan bahwa; Gaya bahasa Iklan Layanan Kesehatan Masyarakat (ILKM), secara diksi atau pilihan kata yang digunakan cenderung bersifat tak resmi, bentuknya umum, singkat dan dapat dipahami oleh masyarakat terpelajar biasa. Dilihat dari sudut nada yang terkandung, narasi teks memiliki gaya bahasa sederhana, biasanya cocok untuk memberi instruksi, perintah, pelajaran, perkuliahan, dan sejenisnya; seperti ujaran yang disampaikan singkat, padat dan jelas, dan bernada himbauan. Dari sisi makna, secara semiotik pemaknaan muncul dari hubungan antara penanda (signifier) dan petanda (signified). Pemaknaan yang muncul dari hubungan tersebut merupakan pemaknaan konotasi. Ideologi yang melatarbelakangi tayangan Iklan Layanan Kesehatan Masyarakat (ILKM), bersumber pada konotasi yang dihasilkan. Penyampaian secara imperatif dan pemakaian simbol, warna, latar temperatur (tanda) seperti termometer misalnya, realisasi makna yang mendominasi adalah makna yang mendekati kewaspadaan dan bahaya bagi kesehatan, seperti warna kuning, putih, dan merah, di samping juga ada warna-warna lain. Hasil penelitian ini menemukan bahwa ILKM berkenaan dengan kebersihan, kesehatan, kewaspadaan, kehati-hatian, kepedulian, kebersamaan, perencanaan, kesejahteraan, dan kebahagiaan.
\end{abstract}

Kata kunci: ILKM, gaya bahasa,makna, ideologi

\begin{abstract}
Public health service advertisements (PHSA) tend to provide information, remind, add value, influence, and even change people's attitudes to healthy living. However, not many public health service advertisements are persuasive, so they do not contribute enough to encourage people to live healthy lives. Therefore, in this research, public health service advertisement which is quite often aired on television media interesting to be examined since it has different characteristic. The purpose of this study was to determine the style of language, meaning, and public health service advertising ideology. The results of this study showed that; The Public Health Service Ads (PHSA) language style, diction or word choice used tends to be informal, general, brief and understandable by ordinary learned societies. Regarding the tone contained, the narrative text had a simple language style, usually suitable to give instructions, commands, lessons, lectures, and the like; such as speech delivered briefly, solid and clear, and appealed. From the meaning point of view, semiotic meaning came from the relation between signifier and signified. The meaning that emerged from the relationship was the meaning of connotation. The ideology that lied behind the impressions of Public Health Service Ads (PHSA), sourced from the resulting connotation. The way to express imperatively as well as the use of symbols, colors, backgrounds (sign) such as thermometers; for instance, the realization of meaning that dominated was the meaning of approaching alertness and danger on health, such as yellow, white, and red, in addition there were other colors. This has determined that PHSA concerned with hygiene, health, precautions, caution, caring, togetherness, planning, prosperity, and happiness.
\end{abstract}

Keywords: PHSA, language style, meaning, ideology

\section{PENDAHULUAN}

Iklan merupakan bentuk wacana persuasi karena iklan mempunyai perbedaan dengan informasi atau pengumuman biasa. Perbedaannya tersebut terletak pada ragam bahasa, retorika penyampaian, dan daya persuasi yang diciptakan. Pada iklan, bahasanya distrategikan agar berdaya persuasi, yaitu mempengaruhi masyarakat agar tertarik dan membeli. Sehubungan dengan tujuan iklan tersebut, Rani (2000: 56) dengan jelas 
mengemukakan bahwa iklan bertujuan untuk menarik perhatian calon konsumen. Istilah persuasi bersumber dari kata Latin, persuasio, yang berarti membujuk, mengajak atau merayu. Persuasi bisa dilakukan secara rasional dan secara emosional. Dengan cara rasional, komponen kognitif pada diri seseorang dapat dipengaruhi. Aspek yang dipengaruhi berupa ide ataupun konsep. Persuasi yang dilakukan secara emosional, biasanya menyentuh aspek afeksi, yaitu hal yang berkaitan dengan kehidupan emosional seseorang. Melalui cara emosional, aspek simpati dan empati seseorang dapat digugah.

Iklan dapat dijumpai di mana saja, mulai dari radio, media cetak, media luar ruang yang berbentuk papan reklame sampai pada iklan televisi. Semuanya mempunyai persamaan, yaitu ingin mendekati khalayak sasaran dengan menarik perhatian mereka. Sebagai wacana persuasi iklan memiliki ciri-ciri tertentu yang dapat dilihat dari segi bahasa, penyajian dan gaya penulisan. Dilihat dari segi bahasa ciri-ciri iklan adalah sebagai berikut: (1) Menggunakan bahasa yang mempengaruhi orang untuk membeli suatu produk; (2) Memperkenalkan suatu produk kepada masyarakat luas; (3) Menggunakan bahasa yang menarik orang untuk mengetahuinya. Dilihat dari gaya penulisan ciri-ciri iklan antara lain (1) Etis, berkaitan dengan kepantasan; (2) Estetis, berkaitan dengan kelayakan (target market, target audiennya, kapan harus ditayangkan; (3) Artistik, bernilai seni sehingga mengundang daya tarik khalayak. Dilihat dari segi penyajian ciri-ciri iklan antara lain: (1) Mempunyai sasaran yang jelas, dengan menentukan target konsumen, yaitu target utama dan target kedua. Media pasang iklan dan penetapan target konsumen tergantung pada kualitas, harga, dan distribusi (jangkauan pemasaran); (2) Mempunyai fokus atas hal yang ingin dikomunikasikan dari produk dan jasa yang diiklankan; (3) Mempunyai daya tarik tertentu hingga konsumen yang disasarnya bisa berhenti untuk memperhatikan isi iklan. Selain kata kata menarik, daya tarik iklan muncul dari desain layout yang menarik.

Dalam dunia periklanan sudah barang tentu proses penyampaiannya menggunakan persuasive appeals atau melalui pendeketan persuasif. Komunikasi persuasif itu sendiri dapat diartikan sebagai sebuah pendekatan komunikasi untuk dapat meyakinkan dan membujuk komunikan -dalam hal ini persuadee dengan sebuah argumen yang menguraikan suatu masalah atau keadaan yang dibuktikan dengan data dan fakta yang bertujuan untuk memengaruhi agar persuadee atau komunikan dapat mengikuti apa yang diharapkan persuader atau komunikator.
Dalam proses penyampaian pesannya menurut Aristoteles terdapat tiga pendekatan dasar komunikasi yang dapat memengaruhi orang lain diantaranya: a. Logical argument (logos), yaitu penyampaian ajakan dengan argumentasi data-data yang dikemukakan, b. Psychological/ emotional argument (pathos), yaitu penyampaian pesan menggunakan efek emosi, Misalnya iklan yang menyenangkan, humoris dan membuat kita mengingat; dan c. Argument based in credibility (ethos), yaitu ajakan atau arahan oleh komunikator yang mempunyai kredibilitas sebagai pakar dalam bidangnya.

Menurut Blake dan Haroldsen (1979) pesan merupakan simbol yang diarahkan secara selektif yang diperuntukkan dalam mengkomunikasikan informasi. Dalam proses komunikasi, pesan yang disampaikan dapat berupa verbal dapat pula nonverbal. Dapat disengaja (intentional), dapat pula tak disengaja (unintentional). Pesan verbal merupakan salah satu faktor yang paling menentukan dalam keberhasilan komunikasi persuasif. Di dalamnya terdapat aspek rangsangan wicara dan penggunaan kata-kata. Tidak setiap rangsangan wicara dapat diterima langsung oleh sasaran, paling tidak hal ini tergantung pada sistem penginderaan, persepsi, perhatian, memori, dan berpikir. Pesan nonverbal terdiri atas body notion atau kinesics behavior, paralanguage, proxemics, olfaction, skin sensitivity to touch dan temperatur, dan use the artifacts. Suatu pesan dikatakan efektif bila makna pesan yang dikirim persuader berkaitan erat dengan makna pesan yang diterima atau ditangkap serta dipahami oleh sasaran.

Iklan layanan kesehatan masyarakat (ILKM) cenderung bertujuan untuk memberikan informasi, mengingatkan, menambah nilai, memengaruhi, dan bahkan mengubah sikap masyarakat untuk hidup sehat. Sebaliknya, tujuan utama dari sebuah iklan komersial lebih pada menjual, di samping juga memberi informasi dan mempengaruhi masyarakat yang sudah merupakan sifat dasar iklan itu sendiri. Namun tidak banyak iklan layanan kesehatan masyarakat bersifat persuasif sehingga tidak cukup berkontribusi maksimal dalam mengajak masyarakat untuk hidup sehat. Oleh karena itu di dalam penelitian ini, iklan layanan kesehatan masyarakat yang cukup sering ditayangkan di media televisi menarik untuk diteliti karena memiliki karakteristik berbeda.

\section{METODE}

Penelitian ini merupakan penelitian kualitatif. Ruang lingkup penelitian ini adalah analisa iklan layanan kesehatan masyarakat dengan menggunakan pendekatan semiotik (Semiotic 
Approach) meliputi gaya bahasa tampilan, makna dan ideologi yang melatarbelakanginya.

\section{HASIL DAN PEMBAHASAN}

Dalam penelitian ini semua data merupakan bagian-bagian cuplikan yang disertai teks narasi dari keseluruhan tayangan iklan. Data yang digunakan berupa video diperoleh dari channel youtubehttps://www.youtube.com/watch? $v=$ VuF9 28jKQs 3 Mei 2015 berjudul 'Pencegahan Demam Berdarah'- Diupload oleh Julia Rgds, Bali, Indonesia. Setelah diolah, data ditampilkan dalam beberapa kutipan dalam bentuk cuplikan gambar berwarna, diruntut berdasarkan alur tayangan iklan, serta dengan transkrip teks yang merupakan konten iklan tersebut. Keseluruhan penggalan tersebut merupakan satu kesatuan isi tayangan. Data yang dipilah per bagian teks narasi yang disampaikan sudah diruntut secara spesifik menjadi sembilan bagian. Hal ini dilakukan agar pembahasan menjadi lebih terperinci dan terstruktur.

Berikut adalah hasil dan pembahasan dalam penelitian ini yang dipresentasikan berurutan.

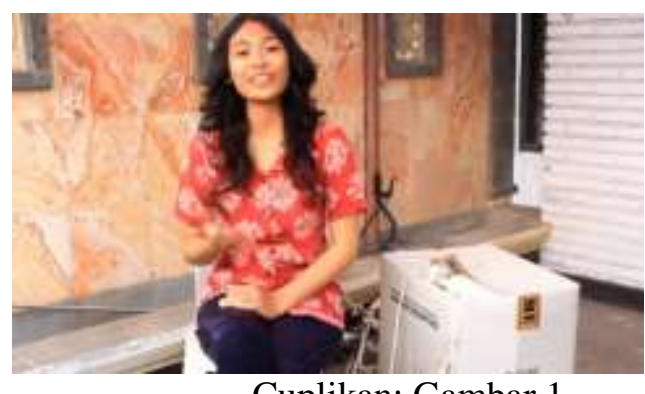

Cuplikan; Gambar 1

Narasi: "Kita tidak pernah tahu kapan penyakit menghampiri kita"....

Berdasarkan cuplikan gambar 1 di atas, dari segi diksi atau pilihan kata, gaya bahasa dalam teks yang dinarasikan oleh perempuan dalam video tersebut bersifat tak resmi, bentuknya umum dan dapat dipahami oleh masyarakat terpelajar biasa. Berdasarkan pengungkapannya, gaya bahasa teks tersebut cenderung diungkapkan secara khias atau metaporis seperti pada kata-kata; "Kita tidak pernah tahu kapan penyakit menghampiri kita "...

Kedua, dari segi makna; terdapat dua sisi pemaknaan yang muncul secara semiotik pada cuplikan tayangan iklan tersebut. Pertama, penanda (signifier) rumah (latar) dengan kardus, sepeda, terlihat berantakan,- dan konsep rumah sebagai petanda (signified). Menurut Barthes (1998), hubungan antara penanda dan petanda (signifiersignified) menentukan makna dari tanda. Sehingga makna yang ditampilkan pertama adalah sebuah rumah yang kurang bersih dan rapi. Konsep makna pertama akan mendukung pemaknaan kedua; yaitu dari teks narasi yang dibawakan, "Kita tidak pernah tahu kapan penyakit menghampiri kita".... Penanda (signifier) penyakit yang dikhiaskan secara metaporis 'menghampiri' Petanda (signified) bermakna konotasi musibah atau bencana bahwa penyakit tertentu 'tidak terprediksi' atau 'tanpa diundang' mendatangi. Makna dari tanda pertama (latar rumah) dan tanda kedua (teks narasi) memiliki hubungan konotasi yaitu rumah yang kurang rapi dan bersih akan membuat suatu penyakit menghampiri penghuni rumah kapan saja. Menurut Roland Barthes. Ideologi berfungsi terutama pada level konotasi, makna sekunder, makna yang sering kali tidak disadari, yang ditampilkan oleh teks dan praktik, atau yang bisa ditampilkan oleh apa pun (Storey, 2003: 8). Sehingga ideologi yang dibangun atau muncul pada cuplikan pertama adalah sebuah citra 'rumah yang kurang rapi dan bersih dianggap tempat berkembangnya penyakit. Ideologi seperti ini masih berkembang di masyarakat.

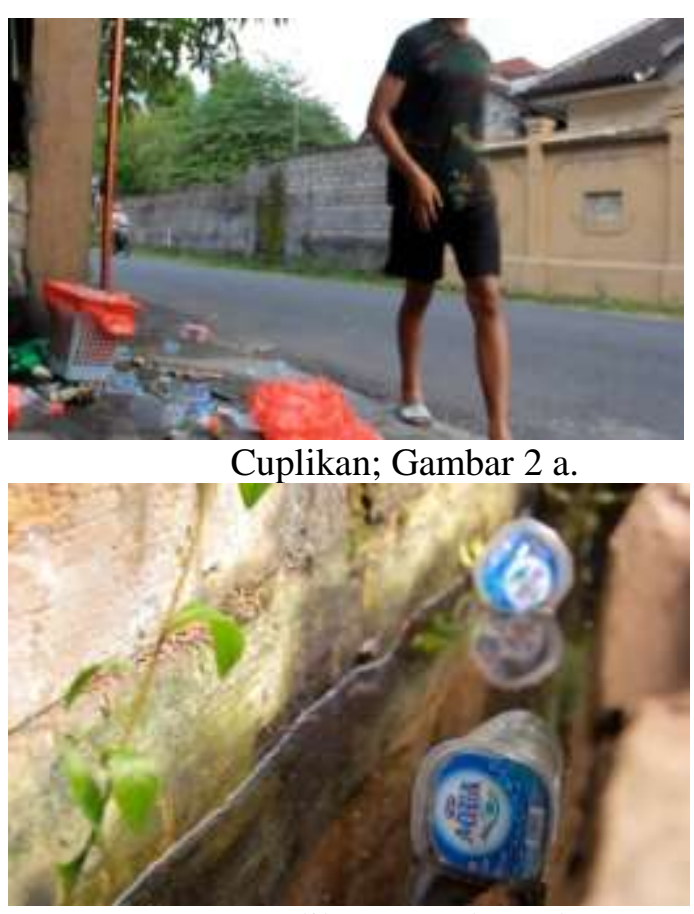

Cuplikan; Gambar 2.b

Narasi: "Terkadang perilaku yang kita lakukan berdampak buruk terhadap kesehatan kita"

Berdasarkan cuplikan gambar $2 \mathrm{a}$ dan $2 \mathrm{~b}$ di atas, dari segi diksi atau pilihan kata, gaya bahasa dalam teks yang dinarasikan oleh perempuan dalam video tersebut bersifat tak resmi, bentuknya umum dan dapat dipahami oleh masyarakat terpelajar biasa. Berdasarkan pengungkapannya, gaya bahasa teks tersebut cenderung diungkapkan secara literal "Terkadang perilaku yang kita lakukan berdampak buruk terhadap kesehatan kita”. 
Kedua, dari segi makna; terdapat dua sisi pemaknaan yang muncul secara semiotik pada cuplikan tayangan iklan tersebut. Pertama, gambar 2a; penanda (signifier) pinggiran jalan (latar) penuh sampah plastik warna-warni berserakan; - dan Pinggiran jalan pada umumnya sebagai petanda (signified). Kedua, pada gambar 2b; penanda (signifier) selokan (latar) berisikan beberapa gelas plastik minuman bekas tertentu buangan orang; dan konsep selokan sebagai petanda (signified). Menurut Barthes (1998), hubungan antara penanda dan petanda (signifier-signified) menentukan makna dari tanda. Sehingga makna yang ditampilkan pertama adalah sebuah konsep pingiran jalan yang kurang bersih dan kotor penuh sampah berserakan, begitu juga pada gambar $2 b$, selokan yang berisikan gelas plastik bekas minuman. Konsep makna pertama akan mendukung pemaknaan kedua; yaitu dari teks narasi yang dibawakan, " "Terkadang perilaku yang kita lakukan berdampak buruk terhadap kesehatan kita”. Penanda (signifier) ..perilaku yang kita lakukan 'berdampak buruk terhadap kesehatan kita dan konsep perilaku (signified) bermakna konotasi 'tidak sehat' bahwa 'perilaku kurang bersih' seperti membuang sampah sembarangan dianggap sebagai sumber atau cikal bakal penyakit. Dan konotasi seperti ini berkembang menjadi asumsi publik yaitu perilaku tersebut berimplikasi negatif_ berakibat buruk bagi kesehatan.

Menurut Roland Barthes, ideologi berfungsi terutama pada level konotasi, makna sekunder, makna yang sering kali tidak disadari, yang ditampilkan oleh teks dan praktik, atau yang bisa ditampilkan oleh apapun (Storey, 2003: 8). Sehingga ideologi yang dibangun atau muncul pada cuplikan (gambar 2a, 2b) adalah sebuah citra 'perilaku mencemari lingkungan berdampak negatif bagi kesehatan masyarakat di sekitarnya'.

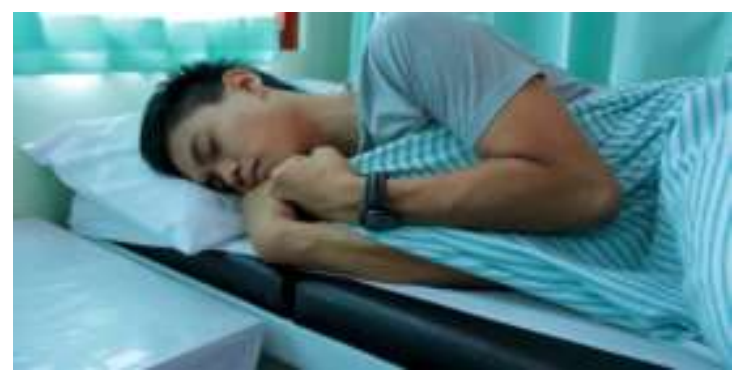

Cuplikan; Gambar 3

Narasi: "Dan.... di saat penyakit mulai menjangkiti kita, waspada! ..Jangan meremehkan!”

Berdasarkan cuplikan gambar 3 di atas, dari segi diksi atau pilihan kata, gaya bahasa dalam teks yang dinarasikan oleh perempuan dalam video tersebut bersifat tak resmi, bentuknya umum dan dapat dipahami oleh masyarakat terpelajar biasa. Berdasarkan gaya bahasa dilihat dari sudut nada yang terkandung, narasi teks di atas memiliki gaya bahasa sederhana, gaya ini biasanya cocok untuk memberi instruksi, perintah, pelajaran, perkuliahan, dan sejenisnya; "Dan.... di saat penyakit mulai menjangkiti kita, waspada! ..Jangan meremehkan!"

Kedua, dari segi makna; terdapat dua sisi pemaknaan yang muncul secara semiotik pada cuplikan tayangan iklan tersebut. Pertama, penanda (signifier) seorang laki-laki terbaring memakai selimut nampak menggigil dengan mata terpejam seperti orang yang sedang tidak enak badan atau menahan sakit (demam) dan konsep tidur memakai selimut sebagai petanda (signified). Menurut Barthes (1998), hubungan antara penanda dan petanda (signifier-signified) menentukan makna dari tanda. Sehingga makna yang ditampilkan pertama adalah seorang laki-laki sedang menahan sakit atau demam. Konsep makna pertama akan mendukung pemaknaan kedua; yaitu dari teks narasi yang dibawakan, "Dan..... di saat penyakit mulai menjangkiti kita, waspada! ..Jangan meremehkan!". Penanda (signifier) penyakit menjangkiti sebagai petanda (signified) bermakna konotasi 'sinyal bahaya'. Makna dari tanda pertama dan tanda kedua (teks narasi) memiliki hubungan konotasi yaitu kondisi demam atau menggigil berindikasi sinyal bahaya bagi siapapun, waspada dan tidak meremehkan, oleh karenanya segera diperlukan penanganan.' Menurut Roland Barthes, ideologi berfungsi terutama pada level konotasi, makna sekunder, makna yang sering kali tidak disadari, yang ditampilkan oleh teks dan praktik, atau yang bisa ditampilkan oleh apa pun (Storey, 2003: 8). Sehingga ideologi yang dibangun atau muncul pada cuplikan ketiga adalah sebuah citra 'seorang lakilaki dalam kondisi demam atau menggigil (bukan karena cuaca dingin secara denotatif) berindikasi sinyal bahaya bagi kesehatan. Ideologi seperti ini masih cukup berkembang di masyarakat.

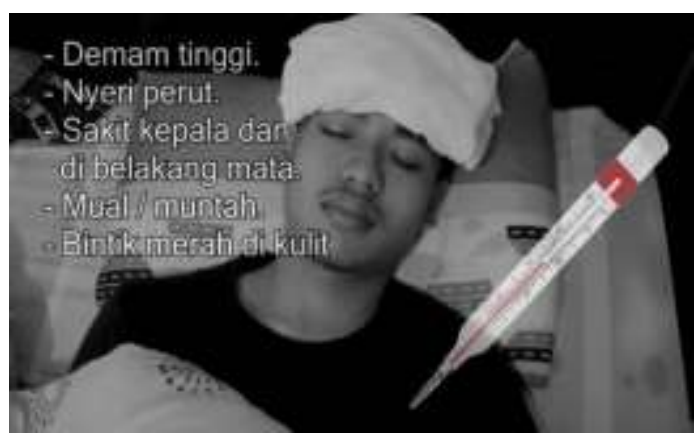

Cuplikan; Gambar 4.

Narasi: ... "Gejala DBD umumnya hampir sama dengan penyakit demam lainnya,... demam tinggi hari pertama"... 
Berdasarkan cuplikan gambar 4 di atas, dari segi diksi atau pilihan kata, gaya bahasa dalam teks yang dinarasikan oleh perempuan dalam video tersebut bersifat tak resmi, bentuknya umum dan dapat dipahami oleh masyarakat terpelajar biasa. Berdasarkan gaya bahasa dilihat dari sudut nada yang terkandung, narasi teks di atas memiliki gaya bahasa sederhana, gaya ini biasanya cocok untuk memberi instruksi, perintah, pelajaran, perkuliahan, dan sejenisnya; "Gejala DBD umumnya hampir sama dengan penyakit demam lainnya,... demam tinggi hari pertama"...

Kedua, dari segi makna; terdapat dua sisi pemaknaan yang muncul secara semiotik pada cuplikan tayangan iklan tersebut. Pertama, penanda (signifier) seorang laki-laki memakai selimut dengan mata terpejam, berbaring dengan kompresan handuk di dahi, dan terdapat gambar termometer - dan konsep seorang lelaki sedang berbaring sebagai petanda (signified). Menurut Barthes (1998), hubungan antara penanda dan petanda (signifier-signified) menentukan makna dari tanda. Sehingga makna yang ditampilkan pertama adalah seorang laki-laki memakai selimut dengan mata terpejam, berbaring dengan kompresan handuk di dahi, dan terdapat gambar termometer - yang mengindikasikan orang tersebut sedang sakit atau sedang demam tinggi. Konsep makna pertama akan mendukung pemaknaan kedua; yaitu dari teks narasi yang dibawakan, "Gejala DBD umumnya hampir sama dengan penyakit demam lainnya,... demam tinggi hari pertama"...

Penanda (signifier) Gejala DBD dan penyakit demam lainnya- demam tinggi hari pertama (signified) bermakna konotasi 'darurat' sehingga dianggap segera memerlukan penanganan serius. Makna dari tanda pertama dan tanda kedua (teks narasi) memiliki hubungan konotasi yaitu seorang laki-laki memakai selimut dengan mata terpejam, berbaring dengan kompresan handuk di dahi, dan terdapat gambar termometer - yang mengindikasikan orang tersebut sedang sakit atau sedang demam tinggi sebagai Gejala DBD yang umumnya hampir sama dengan penyakit demam lainnya,... demam tinggi hari pertama bermakna konotasi darurat. Insert gambar termometer, dengan level suhu tubuh, dan warna merah dan putih, juga mendukung makna konotasi dari tanda medis, yaitu demam tinggi. Menurut Roland Barthes, ideologi berfungsi terutama pada level konotasi, makna sekunder, makna yang sering kali tidak disadari, yang ditampilkan oleh teks dan praktik, atau yang bisa ditampilkan oleh apa pun (Storey, 2003: 8). Sehingga ideologi yang dibangun atau muncul pada cuplikan keempat adalah gejala DBD demam tinggi hari pertama berkonotasi 'darurat'. Ideologi seperti ini masih menjadi asumsi umum di masyarakat.

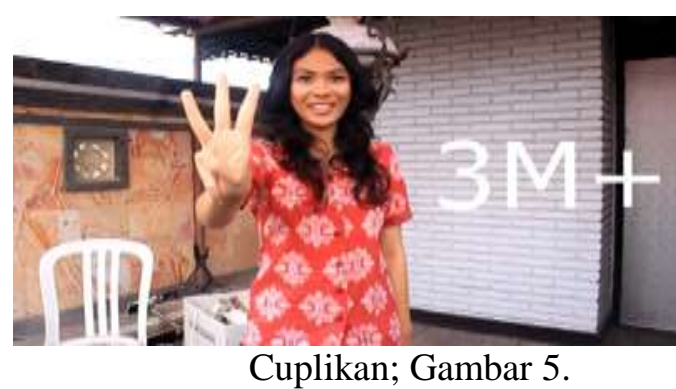

Ajakan/himbauan: "Lakukan pencegahan dengan $3 M+"$

Berdasarkan cuplikan tayangan pada gambar 5 di atas, dari segi diksi atau pilihan kata, gaya bahasa dalam teks yang dinarasikan oleh perempuan dalam video tersebut bersifat tak resmi, bentuknya umum, singkat dan dapat dipahami oleh masyarakat terpelajar biasa. Berdasarkan gaya bahasa dilihat dari sudut nada yang terkandung, narasi teks di atas memiliki gaya bahasa sederhana, gaya ini biasanya cocok untuk memberi instruksi, perintah, pelajaran, perkuliahan, dan sejenisnya; "Lakukan pencegahan dengan $3 M+$ "

Kedua, dari segi makna; terdapat dua sisi pemaknaan yang muncul secara semiotik pada cuplikan tayangan iklan tersebut. Pertama, penanda (signifier) seorang wanita mengacungkan 3 jari tulisan $3 M+$ sebagai petanda (signified). Menurut Barthes (1998), hubungan antara penanda dan petanda (signifier-signified) menentukan makna dari tanda. Sehingga makna yang ditampilkan pertama adalah seorang wanita mengacungkan 3 jari - tulisan $3 M+$ bermakna tiga langkah plus yang harus dilakukan.

Konsep makna pertama akan mendukung pemaknaan kedua; yaitu dari teks narasi yang dibawakan, "Lakukan pencegahan dengan 3M +". Penanda (signifier) Pencegahan - 3M+ sebagai Petanda (signified) bermakna konotasi 'metode/terobosan /langkah-langkah/ strategi' sehingga dianggap sebagai strategi efektif dalam upaya pencegahan. Makna dari tanda pertama dan tanda kedua (teks narasi) memiliki hubungan konotasi yaitu istilah $3 \mathrm{M}+$ dianggap sebagai tiga langkah plus atau strategi efektif dalam upaya pencegahan DBD. Menurut Roland Barthes, ideologi berfungsi terutama pada level konotasi, makna sekunder, makna yang sering kali tidak disadari, yang ditampilkan oleh teks dan praktik, atau yang bisa ditampilkan oleh apa pun (Storey, 2003: 8). Sehingga ideologi yang dibangun atau muncul pada cuplikan tayangan kelima adalah $3 \mathrm{M}+$ yaitu tiga langkah plus yang wajib dilakukan sebagai upaya pencegahan DBD. Konotasi inilah 
yang berkembang sebagai asumsi umum di masyarakat.

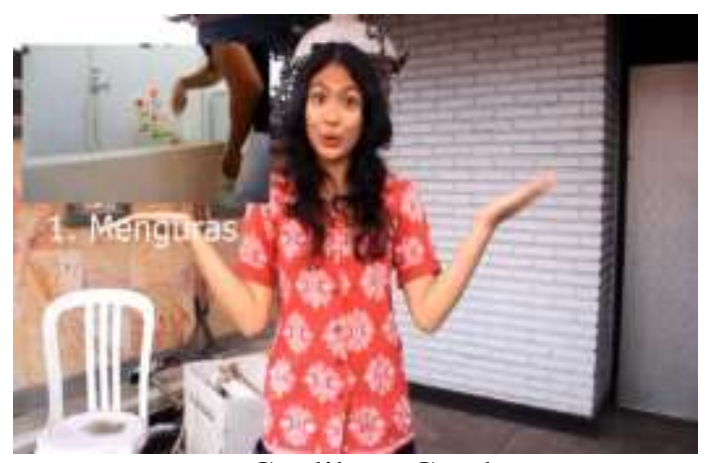

Cuplikan; Gambar 6.

Ajakan/Himbauan: "Pertama, Menguras,

Berdasarkan cuplikan tayangan pada gambar 6 di atas, dari segi diksi atau pilihan kata, gaya bahasa dalam teks yang dinarasikan oleh perempuan dalam video tersebut bersifat tak resmi, bentuknya umum, singkat dan dapat dipahami oleh masyarakat terpelajar biasa. Berdasarkan gaya bahasa dilihat dari sudut nada yang terkandung, narasi teks di atas memiliki gaya bahasa sederhana, gaya ini biasanya cocok untuk memberi instruksi, perintah, pelajaran, perkuliahan, dan sejenisnya; "Pertama, Menguras..."

Kedua, dari segi makna; terdapat dua sisi pemaknaan yang muncul secara semiotik pada cuplikan tayangan iklan tersebut. Pertama, penanda (signifier) seorang dengan pergerakkan kedua tangan terbuka, dengan ekspresi meyakinkan, memaparkan tentang 3M+,----- didukung insert gambar yang menunjukan seseorang sedang menguras bak mandi sebagai petanda (signified). Menurut Barthes (1998), hubungan antara penanda dan petanda (signifier-signified) menentukan makna dari tanda. Sehingga makna yang ditampilkan pertama adalah $M$-Menguras sebagai langkah pertama dari $3 M+$ yang dimaksud adalah Menguras bak mandi/tempat penampungan air (seperti contoh pada insert).

Konsep makna pertama akan mendukung pemaknaan kedua; yaitu dari teks narasi yang dibawakan, "Pertama, Menguras". Penanda (signifier) Menguras - 'konsep menguras' (dalam 3M+) sebagai Petanda (signified) bermakna konotasi 'mengosongkan, membersihkan, tempat penampungan air seperti bak mandi secara rutin, serta mengisinya kembali dengan air bersih' sehingga dianggap sebagai strategi efektif dalam upaya pencegahan. Makna dari tanda pertama dan tanda kedua (teks narasi) memiliki hubungan konotasi yaitu istilah Menguras (3M+) dianggap sebagai langkah pertama dari tiga langkah plus atau strategi efektif dalam upaya pencegahan DBD. Menurut Roland Barthes, ideologi berfungsi terutama pada level konotasi, makna sekunder, makna yang sering kali tidak disadari, yang ditampilkan oleh teks dan praktik, atau yang bisa ditampilkan oleh apa pun (Storey, 2003: 8). Sehingga ideologi yang dibangun atau muncul pada cuplikan tayangan keenam adalah langkah Menguras (3M+). Bak mandi (insert) memiliki mitos sebagai 'sarang nyamuk' karena dianggap tempat bertelurnya nyamuk, sehingga 'menguras' dalam konotasi mengosongkan, mencuci bersih serta mengisikan lagi dengan air bersih, muncul sebagai mitos yang mantap, dan kemudian menjadi ideologi khusus di masyarakat. Hal ini sejalan dengan penelitian Sukarini (2012) yang menemukan bahwa hampir semua ILM berkenaan dengan kebersihan, kesehatan, kewaspadaan, kehati-hatian, kepedulian, kebersamaan, perencanaan, kesejahteraan, dan kebahagiaan.

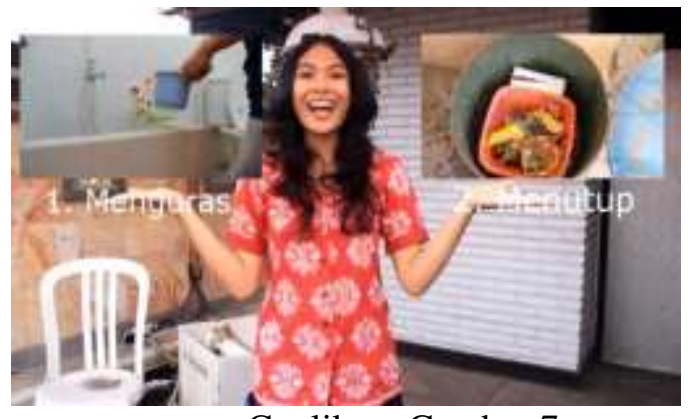

.......kedua Menutup,....

Berdasarkan cuplikan tayangan pada gambar 7 di atas, dari segi diksi atau pilihan kata, gaya bahasa dalam teks yang dinarasikan oleh perempuan dalam video tersebut bersifat tak resmi, bentuknya umum, singkat dan dapat dipahami oleh masyarakat terpelajar biasa. Berdasarkan gaya bahasa dilihat dari sudut nada yang terkandung, narasi teks di atas memiliki gaya bahasa sederhana, gaya ini biasanya cocok untuk memberi instruksi, perintah, pelajaran, perkuliahan, dan sejenisnya; "kedua, Menutup..."

Kedua, dari segi makna; terdapat dua sisi pemaknaan yang muncul secara semiotik pada cuplikan tayangan iklan tersebut. Pertama, penanda (signifier) seorang dengan pergerakkan kedua tangan terbuka, dengan ekspresi meyakinkan, memaparkan tentang 3M+,----- didukung insert gambar (di sisi tangan kiri) yang menunjukan sebua wadah yang berisi sampah sebagai petanda (signified). Menurut Barthes (1998), hubungan antara penanda dan petanda (signifier-signified) menentukan makna dari tanda. Sehingga makna yang ditampilkan pertama adalah $M$-Menutup sebagai langkah kedua dari $3 M+$ yang dimaksud adalah Menutup tempat sampah (seperti contoh pada insert) 
Konsep makna pertama akan mendukung pemaknaan kedua; yaitu dari teks narasi yang dibawakan, "kedua, Menutup". Penanda (signifier) Menutup - 'konsep menutup' (dalam 3M+) Petanda (signified) bermakna konotasi 'menutup tempat-tempat penampungan sampah, air, yang dianggap sebagai strategi efektif dalam upaya pencegahan. Makna dari tanda pertama dan tanda kedua (teks narasi) memiliki hubungan konotasi yaitu istilah Menutup (3M+) dianggap sebagai langkah kedua dari tiga langkah plus atau strategi efektif dalam upaya pencegahan DBD. Menurut Roland Barthes, ideologi berfungsi terutama pada level konotasi, makna sekunder, makna yang sering kali tidak disadari, yang ditampilkan oleh teks dan praktik, atau yang bisa ditampilkan oleh apa pun (Storey, 2003: 8). Sehingga ideologi yang dibangun atau muncul pada cuplikan tayangan keenam adalah langkah Menutup (3M+). Tempat sampah (insert) memiliki mitos sebagai 'sarang nyamuk' karena dianggap tempat berkumpulnya nyamuk, sehingga 'menutup' dalam konotasi menutup tempat-tempat penampungan sampah, air, muncul sebagai mitos yang mantap, dan kemudian menjadi ideologi khusus di masyarakat. Namun, dalam cuplikan tayangan (insert gambar), secara jelas tidak berindikasi langkah atau aksi 'menutup' tempat sampah; sehingga aspek ideologi di balik pesan verbal kurang bersifat persuasif.

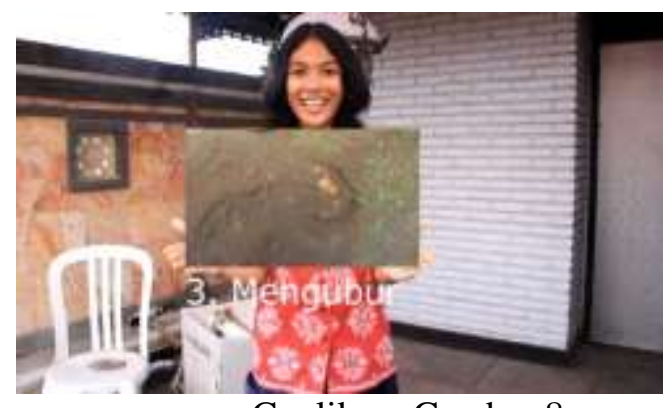

Cuplikan; Gambar 8.

.......Ketiga ,...Mengubur, ..

Berdasarkan cuplikan tayangan pada gambar 8 di atas, dari segi diksi atau pilihan kata, gaya bahasa dalam teks yang dinarasikan oleh perempuan dalam video tersebut bersifat tak resmi, bentuknya umum, singkat dan dapat dipahami oleh masyarakat terpelajar biasa. Berdasarkan gaya bahasa dilihat dari sudut nada yang terkandung, narasi teks di atas memiliki gaya bahasa sederhana, gaya ini biasanya cocok untuk memberi instruksi, perintah, pelajaran, perkuliahan, dan sejenisnya; "ketiga, Mengubur..."

Kedua, dari segi makna; terdapat dua sisi pemaknaan yang muncul secara semiotik pada cuplikan tayangan iklan tersebut. Pertama, penanda (signifier) seorang dengan pergerakkan kedua tangan terbuka, dengan ekspresi meyakinkan, memaparkan tentang $3 M+$, ----- didukung insert gambar (di antara kedua tangan) yang menunjukan sampah yang dikubur sebagai petanda (signified). Menurut Barthes (1998), hubungan antara penanda dan petanda (signifier-signified) menentukan makna dari tanda. Sehingga makna yang ditampilkan pertama adalah $M$-Mengubur sebagai langkah ketiga dari $3 M+$ yang dimaksud adalah Mengubur sampah dalam tanah (seperti contoh pada insert).

Konsep makna pertama akan mendukung pemaknaan kedua; yaitu dari teks narasi yang dibawakan, "ketiga, Mengubur". Penanda (signifier) Mengubur - 'konsep mengubur' (dalam $3 \mathrm{M}+$ ) Petanda (signified) bermakna konotasi 'mengubur sampah/barang barang bekas' yang dianggap sebagai strategi efektif dalam upaya pencegahan. Makna dari tanda pertama dan tanda kedua (teks narasi) memiliki hubungan konotasi yaitu istilah Mengubur $(3 \mathrm{M}+)$ dianggap sebagai langkah ketiga dari tiga langkah plus atau strategi efektif dalam upaya pencegahan DBD. Menurut Roland Barthes, ideologi berfungsi terutama pada level konotasi, makna sekunder, makna yang sering kali tidak disadari, yang ditampilkan oleh teks dan praktik, atau yang bisa ditampilkan oleh apa pun (Storey, 2003: 8). Sehingga ideologi yang dibangun atau muncul pada cuplikan tayangan kedelapan adalah langkah Mengubur (3M+). Barang bekas atau sampah (insert) memiliki mitos sebagai 'sarang nyamuk' karena dianggap tempat berkumpulnya nyamuk, sehingga 'mengubur' dalam konotasi menutupnya di dalam tanah muncul sebagai mitos yang mantap, dan kemudian menjadi ideologi khusus di masyarakat. Namun, dalam cuplikan tayangan (insert gambar), secara jelas tidak berindikasi langkah atau aksi 'mengubur' barang bekas atau sampah; sehingga aspek ideologi di balik pesan verbal kurang bersifat persuasif.

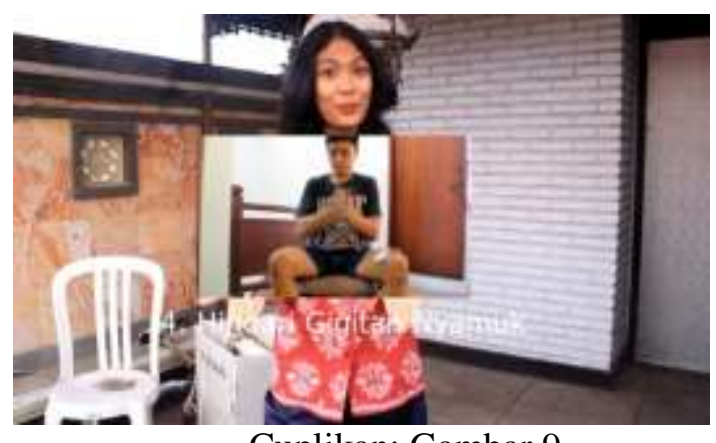

Cuplikan; Gambar 9.

.....dan terakhir Hindari gigitan nyamuk"

Berdasarkan cuplikan tayangan pada gambar 9 di atas, dari segi diksi atau pilihan kata, gaya bahasa dalam teks yang dinarasikan oleh perempuan dalam video tersebut bersifat tak resmi, 
bentuknya umum, singkat dan dapat dipahami oleh masyarakat terpelajar biasa. Berdasarkan gaya bahasa dilihat dari sudut nada yang terkandung, narasi teks di atas memiliki gaya bahasa sederhana, gaya ini biasanya cocok untuk memberi instruksi, perintah, pelajaran, perkuliahan, dan sejenisnya; "dan terakhir, Hindari gigitan nyamuk..."

Kedua, dari segi makna; terdapat dua sisi pemaknaan yang muncul secara semiotik pada cuplikan tayangan iklan tersebut. Pertama, penanda (signifier) seorang dengan pergerakkan kedua tangan terbuka, dengan ekspresi meyakinkan, memaparkan tentang 3M+, ----- didukung insert gambar (di atas kedua tangan) yang menunjukan cuplikan seorang pria menggunakan lotion anti nyamuk sebagai petanda (signified). Menurut Barthes (1998), hubungan antara penanda dan petanda (signifier-signified) menentukan makna dari tanda. Sehingga makna yang ditampilkan pertama adalah Himbauan untuk memakai lotion anti nyamuk sebagai langkah plus dari $3 M+$.

Konsep makna pertama akan mendukung pemaknaan kedua; yaitu dari teks narasi yang dibawakan, "dan terakhir, Hindari gigitan nyamuk". Penanda (signifier) Hindari gigitan nyamuk - 'konsep Hindari/menghindar' (dalam 3M+) Petanda (signified) bermakna konotasi 'berkelit, menjauhkan diri, melindungi diri' dari gigitan nyamuk, yang dianggap sebagai strategi efektif dalam upaya pencegahan. Makna dari tanda pertama dan tanda kedua (teks narasi) memiliki hubungan konotasi yaitu Hindari gigitan nyamuk dengan cara memakai lotion anti nyamuk dianggap sebagai langkah plus dari tiga langkah plus atau strategi efektif dalam upaya pencegahan DBD. Menurut Roland Barthes, ideologi berfungsi terutama pada level konotasi, makna sekunder, makna yang sering kali tidak disadari, yang ditampilkan oleh teks dan praktik, atau yang bisa ditampilkan oleh apa pun (Storey, 2003: 8). Sehingga ideologi yang dibangun atau muncul pada cuplikan tayangan kesembilan adalah langkah Menghindari gigitan nyamuk (3M+). Lotion tertentu (insert) memiliki mitos sebagai 'anti nyamuk' karena dianggap ampuh menjauhkan nyamuk, sehingga 'lotion' dalam konotasi 'anti nyamuk' muncul sebagai mitos yang mantap, dan kemudian menjadi ideologi khusus di masyarakat. Namun, dalam cuplikan tayangan (insert gambar), secara jelas tidak berindikasi langkah atau aksi 'memakai lotion anti nyamuk'; sehingga aspek ideologi di balik pesan verbal kurang bersifat persuasif.

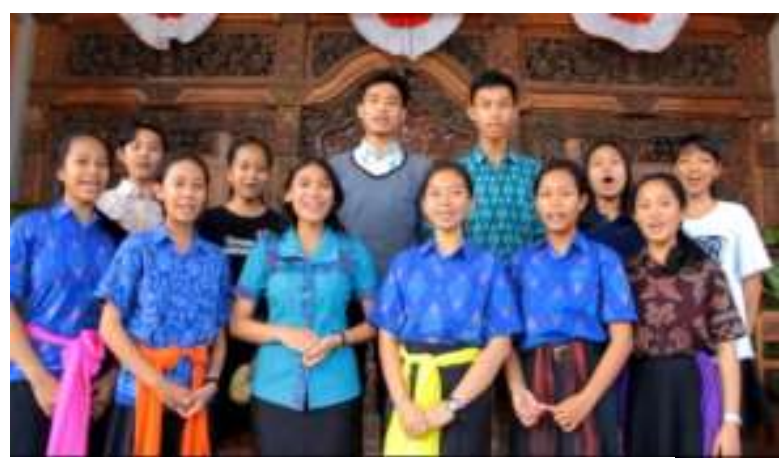

IQLLAN LAYANAN MASYARAKAT INI DIPERSEMBBAHKAN OUEH

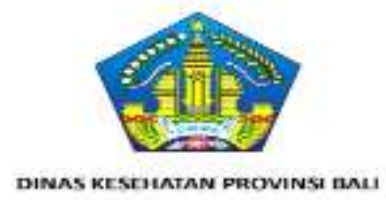

Cuplikan; Gambar 10.

Ajakan/Himbauan: "Mari lindungi orang yang kita sayangi dari Demam Berdarah”...

Berdasarkan cuplikan tayangan pada gambar 10 di atas, dari segi diksi atau pilihan kata, gaya bahasa dalam teks yang dinarasikan oleh perempuan dalam video tersebut bersifat tak resmi, bentuknya umum, singkat dan dapat dipahami oleh masyarakat terpelajar biasa. Berdasarkan gaya bahasa dilihat dari sudut nada yang terkandung, narasi teks di atas memiliki gaya bahasa sederhana, gaya ini biasanya cocok untuk memberi instruksi, perintah, pelajaran, perkuliahan, dan sejenisnya; "Mari lindungi orang yang kita sayangi dari Demam Berdarah"...

Kedua, dari segi makna; pemaknaan yang muncul secara semiotik pada cuplikan tayangan iklan tersebut adalah penanda (signifier), di depan pintuk kayu sejumlah remaja pria dan wanita berkumpul menghadap ke depan menyerukan ajakan----- dan ujaran "Mari lindungi orang yang kita sayangi dari Demam Berdarah"... sebagai petanda (signified). Menurut Barthes (1998), hubungan antara penanda dan petanda (signifiersignified) menentukan makna dari tanda. Petanda (signified) orang yang kita sayangi bermakna konotasi 'keluarga, orang tua, anak, kekasih, teman baik'. Makna dari tanda yang muncul menjadi kurang jelas karena hubungan antara penanda (signifier)-petanda (signified) tidak menghasilkan pemaknaan konotatif. Penanda (signifier) sejumlah remaja pria dan wanita berkumpul menghadap ke depan menyerukan ajakan..., 'tidak mewakili berbagai usia masyarakat' sehingga petanda (signified) 'orang yang kita sayangi' menjadi bias secara konotasi. Menurut Roland Barthes, ideologi berfungsi terutama pada level konotasi, makna sekunder, makna yang sering kali tidak disadari, yang ditampilkan oleh teks dan praktik, atau yang bisa ditampilkan oleh apa pun (Storey, 2003: 8). 
Sehingga ideologi yang dibangun atau muncul pada cuplikan tayangan ke sepuluh juga tidak menonjol atau bersifat persuasif.

\section{SIMPULAN}

Berdasarkan hasil dan pembahasan di atas, dapat ditarik kesimpulan sebagai berikut:

1. Gaya bahasa Iklan Layanan Kesehatan Masyarakat (ILKM), secara diksi atau pilihan kata yang digunakan cenderung bersifat tak resmi, bentuknya umum, singkat dan dapat dipahami oleh masyarakat terpelajar biasa. Berdasarkan gaya bahasa dilihat dari sudut nada yang terkandung, narasi teks memiliki gaya bahasa sederhana, gaya ini biasanya cocok untuk memberi instruksi, perintah, pelajaran, perkuliahan, dan sejenisnya; seperti ujaran yang disampaikan singkat, padat dan jelas, dan bernada himbauan.

2. Dari sisi makna, secara semiotik pemaknaan muncul dari hubungan antara penanda (signifier) dan petanda (signified). Pemaknaan yang muncul dari hubungan tersebut merupakan pemaknaan konotasi yang disampaikan secara imperatif kepada khalayak umum.

3. Ideologi yang melatarbelakangi tayangan Iklan Layanan Kesehatan Masyarakat (ILKM), bersumber pada konotasi yang dihasilkan. Pemakaian simbol dan tanda, seperti termometer, handuk kompres, memiliki realisasi makna yang mendominasi yaitu makna yang mendekati kewaspadaan dan bahaya, seperti warna kuning, putih, dan merah, di samping juga ada warnawarna lain serta cara penyampaianya. Hal ini sejalan dengan penelitian Sukarini yang menemukan bahwa hampir semua ILM Kesehatan berkenaan dengan kebersihan, kesehatan, medis, kewaspadaan, kehati-hatian, kepedulian, kebersamaan, perencanaan, kesejahteraan, dan kebahagiaan.

\section{UCAPAN TERIMA KASIH}

Penulis mengucapakn terimakasih kepada Direktorat Riset dan Pengabdian Masyarakat, Direktorat Jendral Penguatan Riset dan Pengembangan Kemetrian Riset, Teknologi dan Pendidikan Tinggi atas bantuan dana hibah dosen pemula yang telah diberikan.

\section{DAFTAR PUSTAKA}

Barthes, Roland. 2004. Mitologi. Yogyakarta : Kreasi Wacana

Barthes, Roland. 2007. Petualangan Semiologi. Yogyakarta : Pustaka Pelajar

Barthes, Roland. 1998. Semiology and Mytology. Diunduh tanggal 10 Mei 2017 dari id.scribd.com/document/74782034/TeoriSemiotika-Roland-Barthes

Keraf, Gorys. 1991. Gaya Bahasa Retoris dan Kiasan.

Diunduh tanggal 25 Mei 2017 dari najmadewie.blogspot.com/2012/10/gayabahasa-retoris-dan-kiasan.html

Liliweri, Alo. 1992. Dasar-dasar Komunikasi Periklanan. Bandung: Citra Aditya Bakti.

Saussure, Ferdinand de. 1993. Pengantar Linguistik Umum. Diterjemahan oleh Gajah Mada University Press dari buku "Cours de Linguistique Generale”, Yogyakarta

Eco, Umberto. 1979 [1976]. A Theory of Semiotics, Bloomington: Indiana University Press

Eco, Umberto. 1990. The Limits of Interpretation, Indiana University Press, Bloomington and Indianapolis.

www.pps.unud.ac.id/thesis/pdf_thesis/unud-9591652938396-bab ii.pdf

www.scribd.com/.../Sistem-Tanda-Semiotika-TeksDan-Teori-Kode

http://www.landasanteori.com/2015/10/pengertianiklan-layanan-masyarakat.ht 
Suwitra, I.M., Suarjana, N. / Kesehatan Terpadu 2(2) (2018) 